\title{
Article \\ Oxidative Stress Underlies the Ischemia/Reperfusion-Induced Internalization and Degradation of AMPA Receptors
}

\author{
Lindsay M. Achzet ${ }^{1}$, , Clara J. Davison ${ }^{2}$, Moira Shea ${ }^{2}$, Isabella Sturgeon ${ }^{2}$ and Darrell A. Jackson ${ }^{1, *}$ \\ 1 Department of Pharmaceutical Sciences and Molecular Medicine, Washington State University-Health \\ Sciences, Spokane, WA 99201, USA; lindsay.achzet@wsu.edu \\ 2 Department of Biomedical Sciences, University of Montana, Missoula, MT 59802, USA; \\ clara.davison@umontana.edu (C.J.D.); moiraflynnshea@gmail.com (M.S.); \\ isabella.sturgeon@umontana.edu (I.S.) \\ * Correspondence: darrell.jackson@wsu.edu; Tel.: +1-509-368-6542
}

check for

updates

Citation: Achzet, L.M.; Davison, C.J.; Shea, M.; Sturgeon, I.; Jackson, D.A. Oxidative Stress Underlies the Ischemia/Reperfusion-Induced Internalization and Degradation of AMPA Receptors. Int. J. Mol. Sci. 2021, 22, 717. https://doi.org/ 10.3390/ijms22020717

Received: 30 November 2020 Accepted: 11 January 2021 Published: 13 January 2021

Publisher's Note: MDPI stays neutral with regard to jurisdictional clai$\mathrm{ms}$ in published maps and institutional affiliations.

Copyright: (C) 2021 by the authors. Licensee MDPI, Basel, Switzerland. This article is an open access article distributed under the terms and conditions of the Creative Commons Attribution (CC BY) license (https:// creativecommons.org/licenses/by/ $4.0 /)$.

\begin{abstract}
Stroke is the fifth leading cause of death annually in the United States. Ischemic stroke occurs when a blood vessel supplying the brain is occluded. The hippocampus is particularly susceptible to AMPA receptor-mediated delayed neuronal death as a result of ischemic/reperfusion injury. AMPA receptors composed of a GluA2 subunit are impermeable to calcium due to a posttranscriptional modification in the channel pore of the GluA2 subunit. GluA2 undergoes internalization and is subsequently degraded following ischemia/reperfusion. The subsequent increase in the expression of GluA2-lacking, $\mathrm{Ca}^{2+}$-permeable AMPARs results in excitotoxicity and eventually delayed neuronal death. Following ischemia/reperfusion, there is increased production of superoxide radicals. This study describes how the internalization and degradation of GluA1 and GluA2 AMPAR subunits following ischemia/reperfusion is mediated through an oxidative stress signaling cascade. U251-MG cells were transiently transfected with fluorescently tagged GluA1 and GluA2, and different Rab proteins to observe AMPAR endocytic trafficking following oxygen glucosedeprivation/reperfusion (OGD/R), an in vitro model for ischemia/reperfusion. Pretreatment with Mn(III)tetrakis(1-methyl-4-pyridyl)porphyrin (MnTMPyP), a superoxide dismutase mimetic, ameliorated the OGD/R-induced, but not agonist-induced, internalization and degradation of GluA1 and GluA2 AMPAR subunits. Specifically, MnTMPyP prevented the increased colocalization of GluA1 and GluA2 with Rab5, an early endosomal marker, and with Rab7, a late endosomal marker, but did not affect the colocalization of GluA1 with Rab11, a marker for recycling endosomes. These data indicate that oxidative stress may play a vital role in AMPAR-mediated cell death following ischemic/reperfusion injury.
\end{abstract}

Keywords: ischemic/reperfusion injury; AMPA receptor; GluA1; GluA2; reactive oxygen species; oxygen glucose-deprivation/reperfusion (OGD/R); in vitro

\section{Introduction}

Stroke is responsible for the death of nearly 140,000 people in the United States annually. Of the estimated 800,000 strokes that occur in the United States each year, approximately $87 \%$ are ischemic [1]. Ischemic stroke occurs when a blood vessel in the brain is blocked, hindering the vessel's ability to provide oxygen and nutrients to brain tissue. While it is necessary to reintroduce blood flow to the infarcted area, this act also results in further damage by inflammation, oxidative stress, and delayed neuronal death (DND) within vulnerable neuronal populations, including CA1 hippocampal pyramidal neurons [2,3]. During ischemia, the lack of energy available disrupts ATP-dependent processes that maintain ionic gradients, which are critical to cellular survival. Disrupting the ionic balance leads to excessive release of neurotransmitters, including glutamate, which are unable to be effectively cleared from synapses [4]. Excessive stimulation of $\mathrm{N}$-methyl$D$-aspartate receptors (NMDARs) by glutamate is a contributing factor to DND [5-8], but 
multiple studies have reported that $\alpha$-amino-3-hydroxy-5-methyl-4-isoxazolepropionic acid receptors (AMPARs) also contribute to DND [9-14].

AMPARs are ionotropic glutamate receptors composed of GluA1-4 subunits and can be either homomeric or heteromeric tetramers [15]. A majority of AMPARs are impermeable to $\mathrm{Ca}^{2+}$ due to a post-transcriptional modification in the channel pore of the GluA2 AMPAR subunit [16]. Increases in intracellular calcium under physiological conditions regulates many cellular processes, including synaptic plasticity. The overactivation of postsynaptic receptors, such as NMDA receptors and $\mathrm{Ca}^{2+}$-permeable AMPARs, leads to an overload of intracellular calcium. This is a key event responsible for a large amount of neuronal death associated with stroke [17]. This process is tightly regulated under physiological conditions, and its dysregulation in pathophysiological conditions, such as ischemic stroke, is catastrophic.

Long-term potentiation (LTP), or strengthening of the synapse, is a tightly regulated process underlying how we form memories and learn. In the simplest form of LTP, AMPARs are inserted into the postsynaptic membrane. During long-term depression (LTD), or weakening of the synapse, AMPARs are removed from the postsynaptic membrane [18]. The incorporation of GluA2-lacking, $\mathrm{Ca}^{2+}$-permeable AMPARs into the postsynaptic membrane is important in the induction of LTP [19]. However, when this GluA2 subunit composition switch from GluA2-containing, $\mathrm{Ca}^{2+}$-impermeable AMPARs to GluA2-lacking, $\mathrm{Ca}^{2+}$-permeable AMPARs becomes long-lasting, the results are detrimental to the cell and contribute to neuronal death in a number of central nervous system pathologies, including stroke [13]. As a result of ischemia/reperfusion, AMPARs undergo a subunit composition switch from $\mathrm{Ca}^{2+}$-impermeable, GluA2-containing AMPARs [20], to $\mathrm{Ca}^{2+}$-permeable, GluA2-lacking AMPARs. This allows the AMPAR to conduct calcium which, in combination with excessive NMDAR stimulation, exacerbates cell death [21].

During ischemia/reperfusion there is a triphasic burst of superoxide. Upon hypoxic onset, superoxide is produced by the mitochondria as a byproduct from the dysregulated electron transport chain. Next in the hypoxic phase, the cytosolic enzyme xanthine oxidase produces reactive oxygen species, including hydrogen peroxide and superoxide. Once blood flow is restored during the reperfusion phase, NADPH oxidase, a membrane-bound superoxide generator, produces a large burst of superoxide [22]. Additional sources of reactive oxygen species following ischemic/reperfusion injury include monoamine oxidase, catecholamine metabolism, quinone formation, and oxidation of unsaturated fatty acids [23].

In this study, we show that internalization and degradation of GluA2-containing AMPARs following ischemia/reperfusion is mediated through an oxidative stress signaling cascade. U251-MG, a human astroglioma cell line, was utilized in this study due to its high transfection efficiency and consistent response to oxygen-glucose deprivation/reperfusion (OGD/R), an in vitro model for ischemic stroke. U251-MG cells have been used extensively to study various signaling pathways and protein trafficking [24-30]. U251-MG cells were transiently transfected with fluorescently tagged GluA1 and GluA2, as well as different Rab proteins to examine endocytic/intracellular trafficking of AMPARs following OGD/R. Rab proteins are GTPases that alternate between an inactive GDP-bound state, and an active GTP-bound state. The active GTP-bound state of Rab proteins allows them to interact with downstream effectors [31]. Previous studies have utilized pHluorin-tagged plasmids to observe AMPAR trafficking [32,33], but these tags have proven problematic [34]. In order to clarify the trafficking and intracellular localization of GluA1 and GluA2 AMPAR subunits following OGD/R, we utilized various Rab proteins as biomarkers. Rab5 is localized to early endosomes [35]. Rab7 is localized to late endosomes destined for lysosomal degradation [36]. Rab11 is localized to recycling endosomes that undergo exocytosis [37]. To examine whether superoxide plays a role in AMPAR trafficking following OGD/R, we pretreated the transfected U251-MG cells with Mn(III)tetrakis(1-methyl-4-pyridyl)porphyrin (MnTMPyP), a cell-permeable superoxide dismutase mimetic, and examined the endocytic trafficking of GluA2 and GluA2 AMPAR subunits following OGD/R. Interestingly, we 
identified oxidative stress-dependent differential trafficking patterns between GluA1 and GluA2 AMPAR subunits following OGD/R.

\section{Results}

\subsection{OGD/R Did Not Alter Cell Viability in U251-MG Cells}

We first sought to determine whether our model of OGD/R resulted in increased cell death compared to normoxic controls. There was no significant difference in cell viability by trypan blue exclusion in the OGD/R-exposed cells compared to the normoxic control (Figure 1), confirming that our in vitro model of ischemia/reperfusion is not lethal and any differences in protein levels are not a result of cell death.

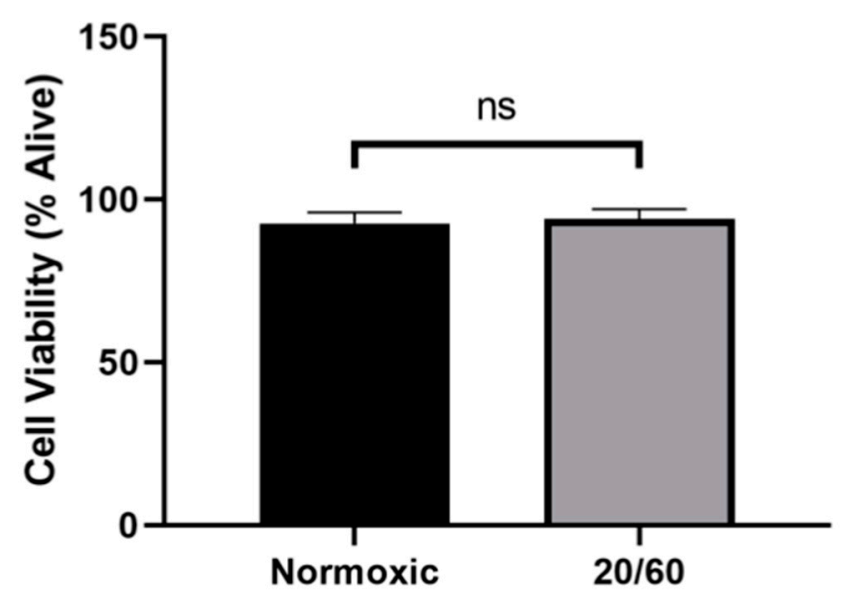

Figure 1. Oxygen-glucose deprivation/reperfusion (OGD/R) does not alter the viability of U251-MG cells. U251-MG cells underwent OGD for $20 \mathrm{~min}$, followed by reperfusion for $60 \mathrm{~min}$. There was no significant difference between the viability of normoxic control U251-MG cells and OGD/R-treated U251-MG cells ( $\mathrm{n}=3$; unpaired student $t$-test). ns denotes no significance.

\subsection{MnTMPyP Pretreatment Did Not Prevent Agonist-Induced Internalization of AMPARs}

To examine whether our superoxide dismutase mimetic, MnTMPyP, prevents agonistinduced internalization, we first exposed U251-MG cells to 3 min of agonist stimulation $(100 \mu \mathrm{M}$ AMPA; $100 \mu \mathrm{M}$ cyclothiazide) in the presence or absence of MnTMPyP $(100 \mu \mathrm{M})$. Following the 3 min of AMPA/cyclothiazide stimulation, cells were fixed at 5- or 10-min time-points. There was an increase in colocalization between GluA1 and Rab5, and GluA2 and Rab5 following AMPA stimulation (Figure 2). This increased colocalization indicates that GluA1 and GluA2 AMPAR subunits were internalized and presented within Rab5positive early endosomes. Agonist-induced internalization of GluA1 and GluA2 in Rab5positive endosomes was not antagonized by MnTMPyP.

OGD/R has been previously shown to produce reactive oxygen species (ROS) in hippocampal and cortical neurons [22], and we wanted to examine whether we observe a similar effect in our model system. Utilizing a nitroblue tetrazolium (NBT) assay, we determined that U251-MG cells produce ROS in a time-dependent manner with OGD/R exposure. Phorbol 12-myristate 13-acetate (PMA) activates NADPH oxidase resulting in increased ROS production [38] and was utilized as a positive control for the NBT assay. ROS production following $\mathrm{OGD} / \mathrm{R}$ was first observed at reperfusion time-point $15 \mathrm{~min}$, and maximally produced with 60 min of reperfusion. Pretreatment with MnTMPyP ameliorated this OGD/R-induced increase in ROS (Figure 3). Based upon previous results [39,40] within our lab, we sought to determine whether superoxide production had a direct effect on AMPAR subunit endocytic trafficking following OGD/R. 
A)

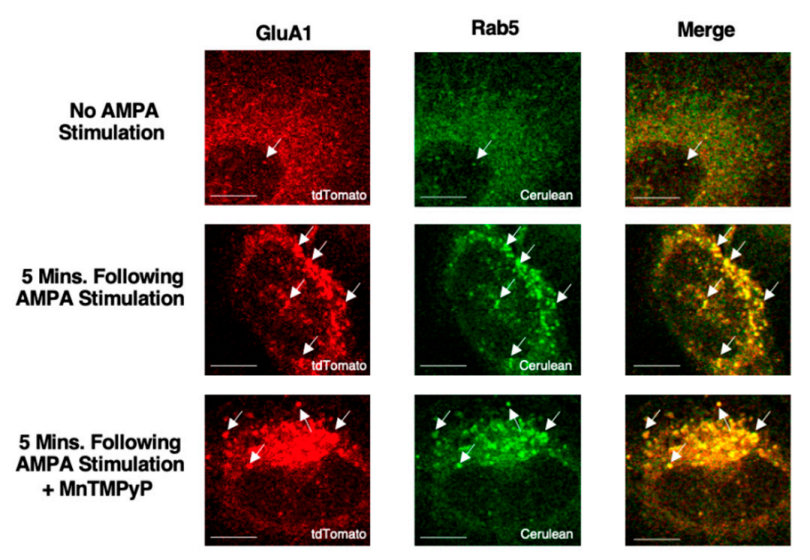

B)

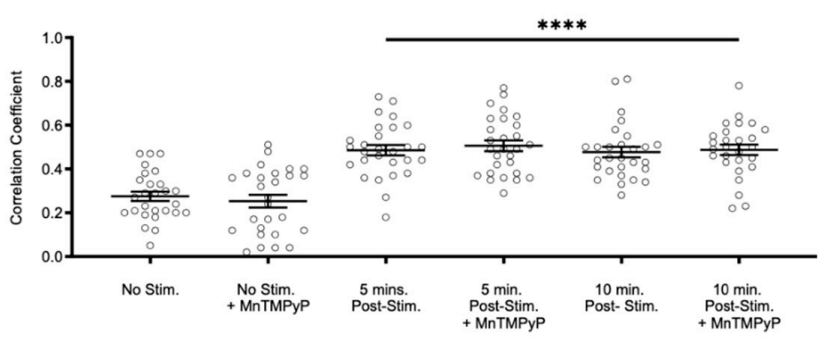

C)

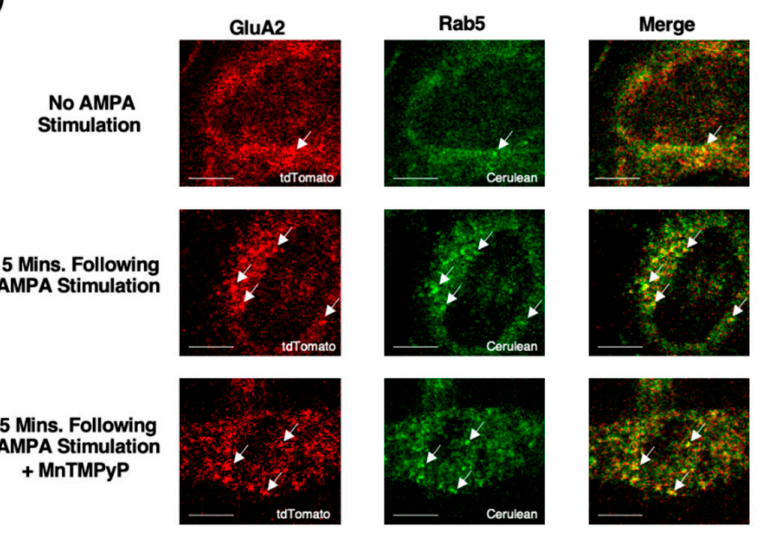

D)

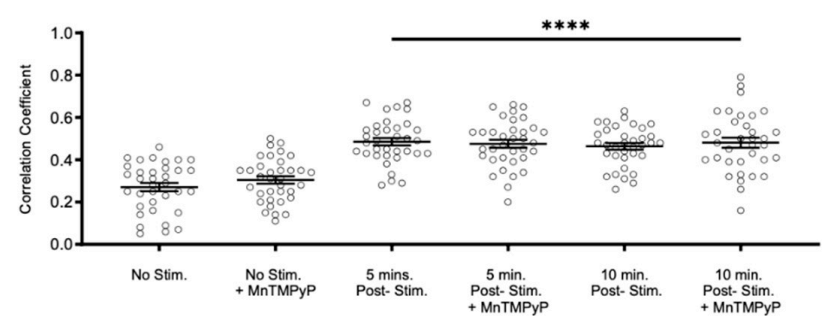

Figure 2. Pretreatment with Mn(III)tetrakis(1-methyl-4-pyridyl)porphyrin (MnTMPyP) did not prevent agonist-induced internalization of AMPARs. U251-MG cells transfected with either GluA1-tdTomato or GluA2-tdTomato and Rab5-cerulean, an early endosomal marker, and stimulated with AMPA agonist [100 $\mu \mathrm{M}]$. (A,B) Increased colocalization between GluA1 and Rab5, and GluA2 and Rab5, respectively. This indicates internalization following agonist stimulation, which was unaffected by pretreatment with MnTMPyP, a superoxide scavenger. $(\mathbf{C}, \mathbf{D})$ are quantifications of $(\mathbf{A}, \mathbf{B})$, respectively $(\mathrm{n}=30)$. **** $p<0.0001$; ANOVA with Tukey's post hoc test comparing agonist conditions to corresponding controls (no agonist stimulation \pm MnTMPyP). Data are expressed as mean \pm SEM. Scale bar is $100 \mu \mathrm{M}$. Arrows indicate colocalization. 


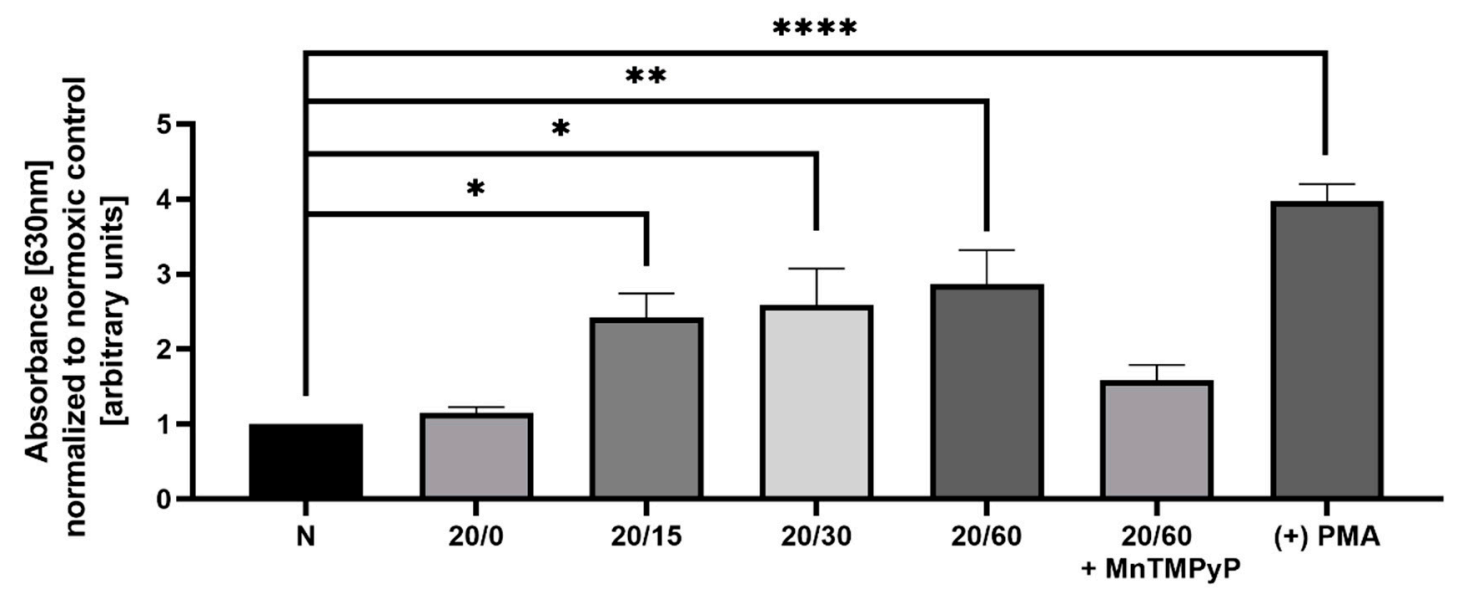

Figure 3. Pretreatment of OGD/R-exposed U251-MG cells with MnTMPyP antagonized reactive oxygen species (ROS) generation. Spectrophotometric quantification of ROS following either OGD/R or normoxic conditions with or without pre-treatment of MnTMPyP $(100 \mu \mathrm{M})$ utilizing nitroblue tetrazolium chloride (NBT), to examine ROS production $(\mathrm{n}=3)$. Phorbol 12-myristate 13-acetate (PMA; $1 \mu \mathrm{M}$ for $15 \mathrm{~min}$ ) was used as a positive control. ${ }^{*} p<0.05 ;{ }^{* *} p<0.01 ;{ }^{* * * *} p<0.0001$; ANOVA with Tukey's post hoc test comparing OGD/R conditions to normoxic control \pm MnTMPyP). Data are expressed as mean \pm SEM.

2.3. Pretreatment with MnTMPyP Attenuated the OGD/R-Induced Internalization of GluA1 and GluA2 AMPAR Subunits

Since our model system, U251-MG cells, produced ROS during OGD/R, we wanted to determine whether pretreatment with a superoxide scavenger, MnTMPyP, affected the endocytic trafficking of AMPAR subunits, GluA1 and GluA2. Following OGD/R, GluA1 and GluA2 subunits were both highly colocalized with Rab5-positive early endosomes. Interestingly, the time-points of GluA1 and GluA2 internalization differed with OGD/R. GluA1 was highly colocalized with Rab5 at OGD/R-5 and OGD/R-15-min time-points. GluA2 colocalized with Rab5-positive early endosomes solely at the OGD/R-5-min time-point, indicating that GluA2 moved quickly within the endocytic pathway from an early endosome to a sorting endosome, or a Rab7-positive late endosome. GluA1 and GluA2 transiently transfected in U251-MG cells internalized following OGD/R exposure. To determine whether oxidative stress played a role in this internalization, we pretreated the U251MG cells with MnTMPyP. Pretreatment with MnTMPyP attenuated the OGD/R-induced colocalization of both GluA1 and GluA2 with Rab5-positive early endosomes (Figure 4).

\subsection{GluA1 and GluA2 AMPAR Subunits Did Not Undergo OGD/R-Induced Degradation in the Presence of MnTMPyP}

Following GluA1 and GluA2 AMPAR subunit internalization to Rab5-positive endosomes, experiments were performed to examine whether GluA1 or GluA2 AMPAR subunits are trafficked to Rab11-positive recycling endosomes in cells subjected to OGD/R. GluA1 remained highly colocalized with Rab11-positive recycling endosomes under both normoxic and OGD/R conditions. Treatment with MnTMPyP had no effect on this colocalization under normoxic nor OGD/R conditions (Figure 5A,C). Conversely, GluA2 was not highly colocalized with Rab11-positive recycling endosomes under any conditions, with or without MnTMPyP treatment. (Figure 6A,C). It is likely that there was a recycling pool of GluA1 homomeric AMPARs under both basal and pathologic conditions, but not GluA2-containing AMPARs. 
A)

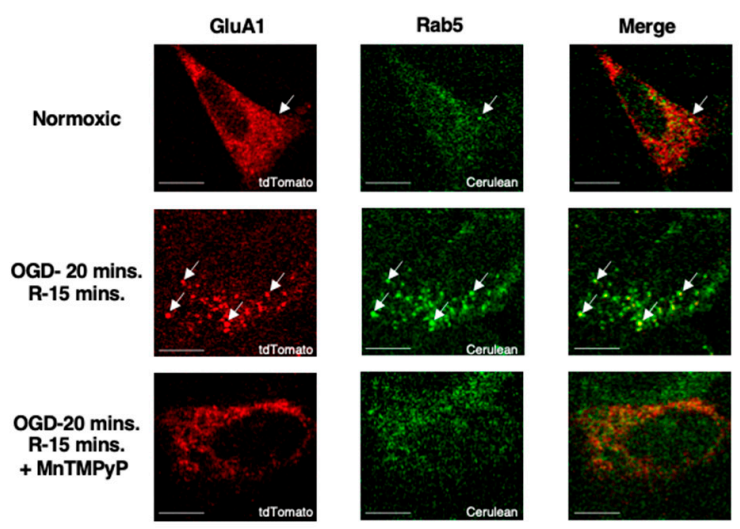

B)

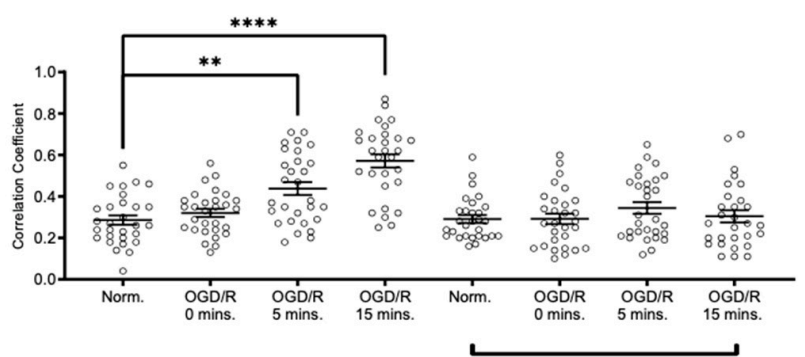

C)

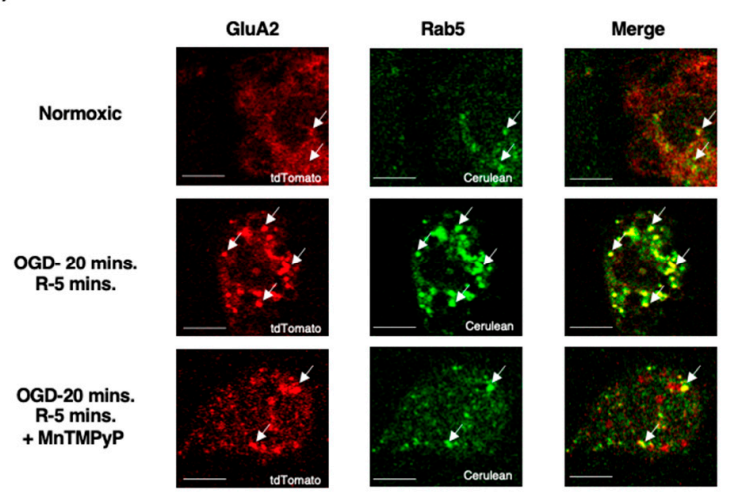

D)

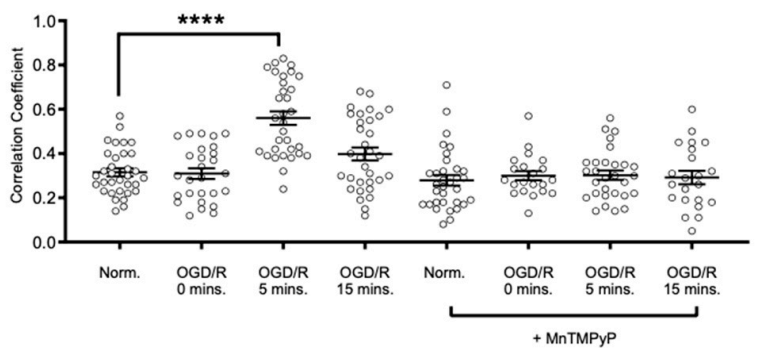

Figure 4. MnTMPyP prevented OGD/R-induced internalization of GluA1 and GluA2 AMPAR subunits. U-251 MG cells transfected with either GluA1-tdTomato or GluA2-tdTomato, and Rab5-cerulean, an early endosomal marker, and exposed to either normoxic or OGD/R conditions. (A) Increased colocalization between GluA1 and GluA2, indicating internalization, maximally at OGD/R-15 min; the effect was ameliorated with pretreatment of MnTMPyP, a superoxide scavenger. (B) Quantification of (A) microscopy $(n=30)$. (C) Increased colocalization between GluA2 and Rab5, indicating internalization, maximally at OGD/R-5 min; the effect was ameliorated with pretreatment of MnTMPyP. (D) Quantification of (C) microscopy results $(\mathrm{n}=30) .{ }^{* *} p<0.01 ; * * * * p<0.0001$; ANOVA with Tukey's post hoc test comparing OGD/R conditions to the corresponding control (normoxic \pm MnTMPyP). Data are expressed as mean \pm SEM. Scale bar is $100 \mu \mathrm{M}$. Arrows indicate colocalization. 
To examine whether AMPAR subunits were being trafficked to the degradative pathway following OGD/R, we examined their colocalization with Rab7-positive late endosomes destined for lysosomal degradation. Both GluA1 and GluA2 subunits were highly colocalized with Rab7-positive late endosomes following OGD/R, likely indicating they were fated for degradation (Figure 5B,D and Figure 6B,D). Pretreatment with MnTMPyP, scavenging superoxide, prevented GluA1 and GluA2 AMPAR subunits being sorted to Rab7-positive late endosomes. This may occur because MnTMPyP treatment prevents the AMPAR subunits from internalizing with OGD/R or it prevents GluA1 and GluA2 subunits from trafficking to Rab7-positive endosomes with OGD/R exposure.

To further confirm that GluA1 and GluA2 subunits are degraded with OGD/R, we performed Western blot analysis to examine their respective protein levels. As expected, both GluA1 and GluA2 are degraded in a time-dependent manner with OGD/R. GluA1 protein levels decreased at OGD/R-30-min and maximally at OGD/R-60-min time-points. GluA2 protein levels decreased at the OGD/R-60-min time-point. Pretreatment with MnTMPyP prevented the OGD/R-induced degradation of GluA1 partially, and GluA2 completely (Figure 7).

A)

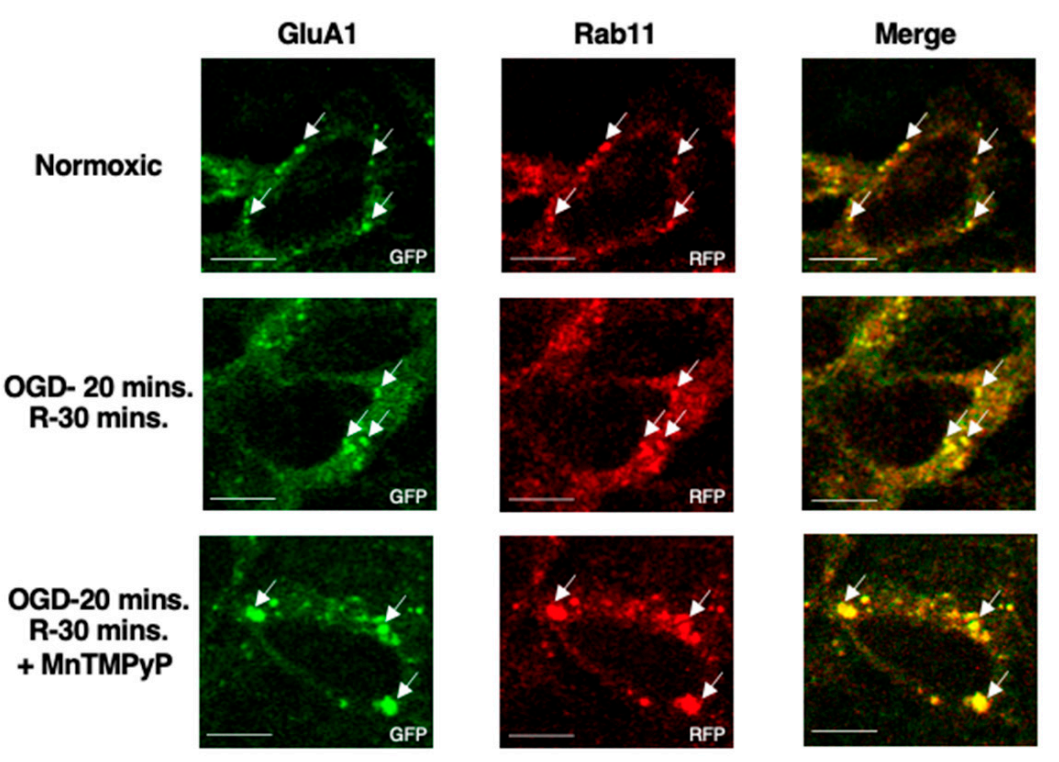

B)

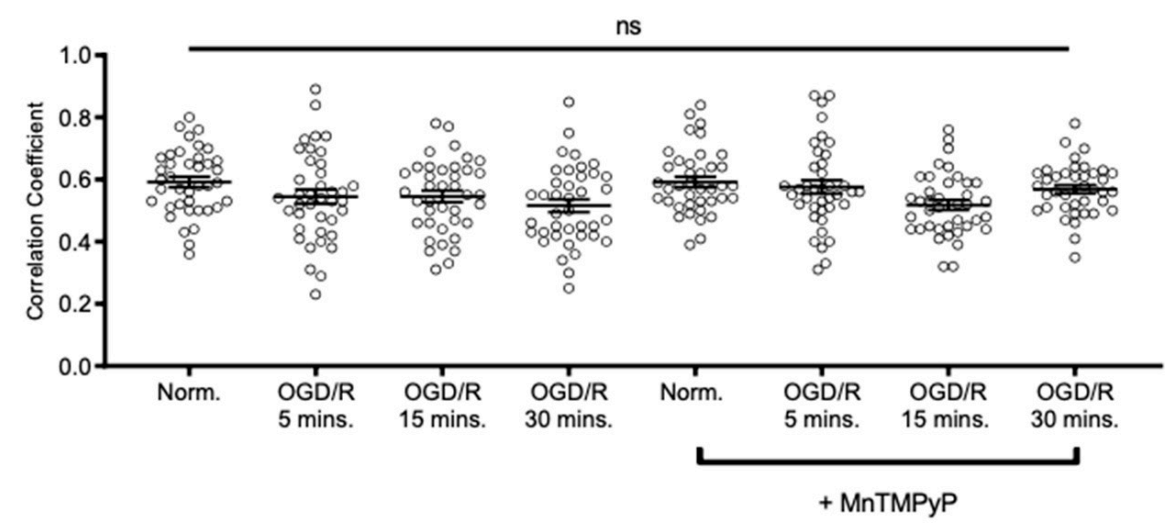

Figure 5. Cont. 
C)
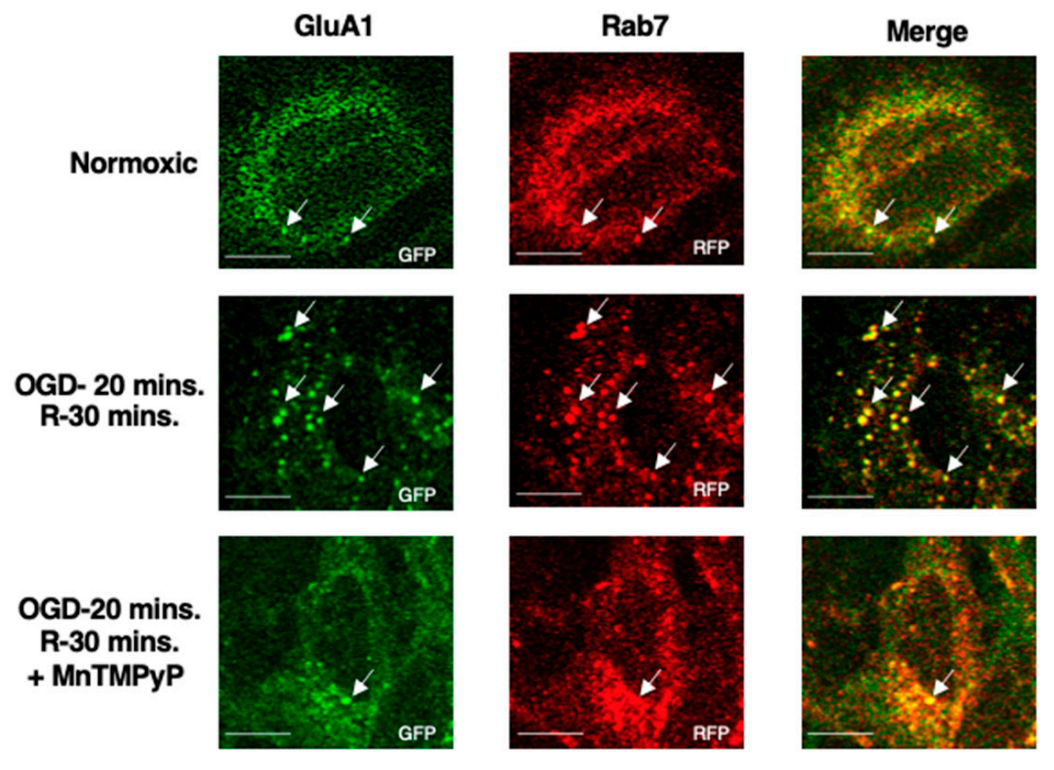

D)

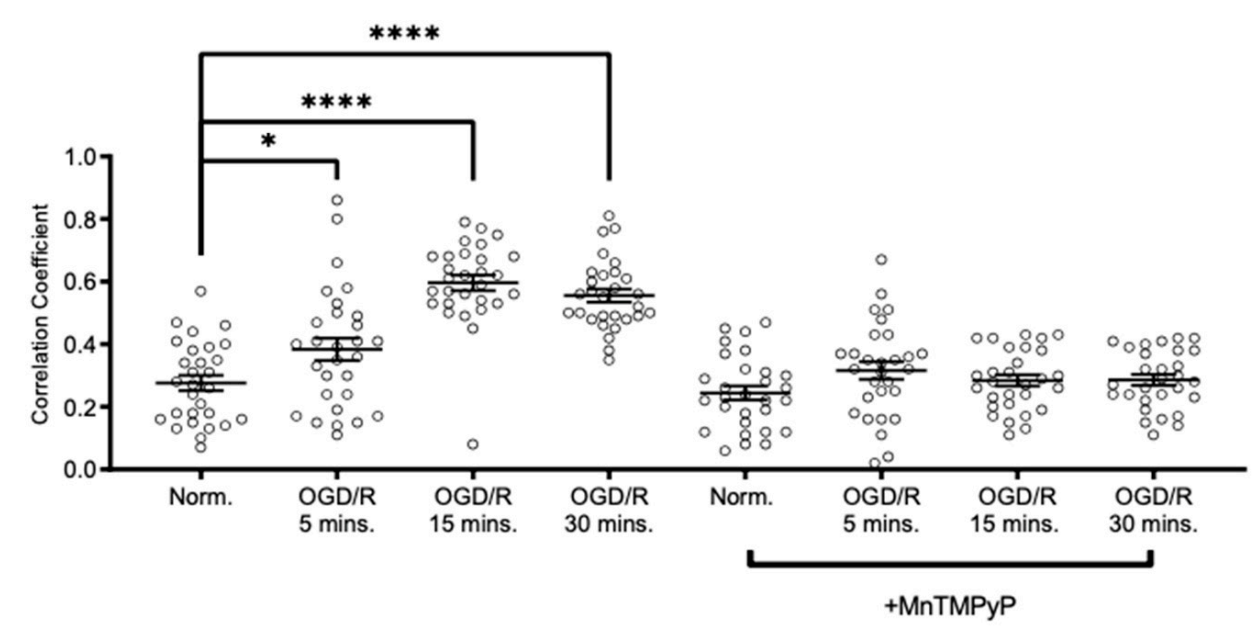

Figure 5. MnTMPyP prevented OGD/R-induced Rab-7, late endosomal sorting of GluA1 AMPAR subunits. GluA1 was present in Rab11-positive endosomes under all conditions. U-251 MG cells transfected with GluA1-eGFP and either Rab11-RFP, a recycling endosome marker, or Rab7-RFP, a marker for late endosomes, and exposed to either normoxic or OGD/R conditions. (A) High colocalization between GluA1 and Rab11 under both normoxic and OGD/R condition, unaffected by MnTMPyP treatment. (B) Quantification of (A) microscopy experiments $(\mathrm{n}=30)$. (C) Increased colocalization between GluA1 and Rab7, indicating lysosomal degradation, maximally at OGD/R-15 min; the effect was ameliorated with pretreatment of MnTMPyP. (D) Quantification of microscopy $(\mathrm{n}=30)$ results from $(\mathbf{C}){ }^{*} p<0.05 ;{ }^{* * *} p<0.0001$; ns denotes no significance; ANOVA with Tukey's post hoc test comparing OGD/R conditions corresponding to control (normoxic \pm MnTMPyP). Data are expressed as mean \pm SEM. Scale bar is $100 \mu \mathrm{M}$. Arrows indicate colocalization. 
A)

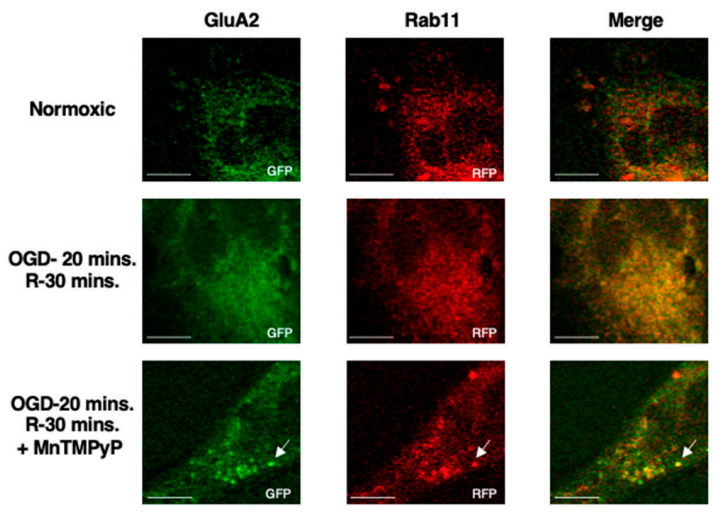

B)

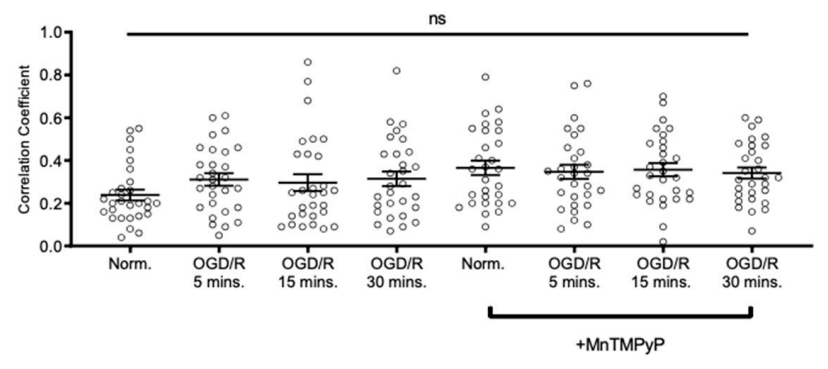

C)

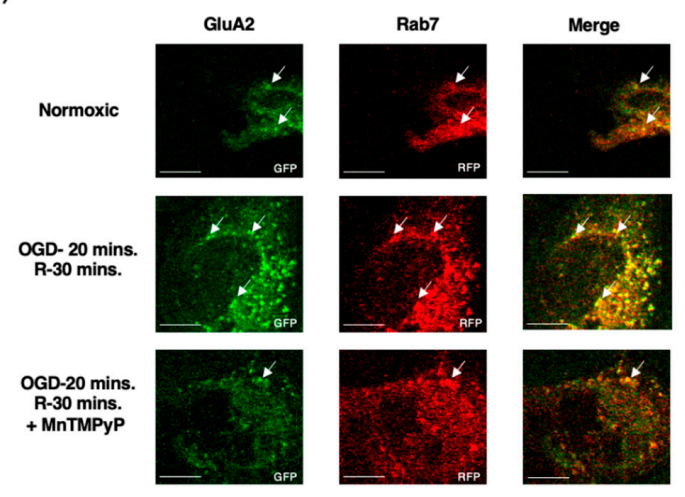

D)

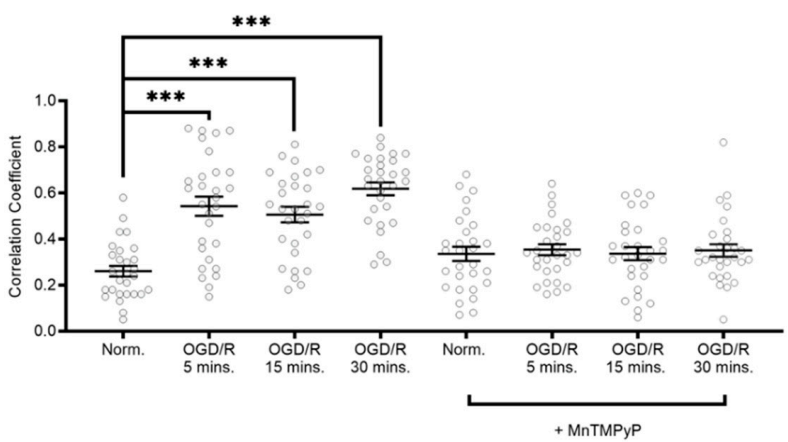

Figure 6. MnTMPyP prevented OGD/R-induced Rab-7, late endosomal sorting of GluA2 AMPAR subunits. GluA2 was not present in Rab11, recycling endosomes under any conditions. U-251 MG cells transfected with GluA2-eGFP, and either Rab11-RFP, a recycling endosome marker, or Rab7-RFP, a marker for late endosomes, and exposed to either normoxic or OGD/R conditions. (A) GluA2 did not colocalize with Rab11 under normoxic nor OGD/R conditions. (B) Quantification of microscopy $(n=30)$ results from (A). (C) Increased colocalization between GluA2 and Rab7, indicating lysosomal degradation, maximally at OGD/R-30 min; the effect was ameliorated with pretreatment of MnTMPyP. D) Quantification of microscopy $(\mathrm{n}=30)$ results from $(\mathrm{C}) .{ }^{* * *} p<0.001$; ANOVA with Tukey's post hoc test comparing OGD/R conditions to corresponding control (normoxic $\pm \mathrm{MnTMPyP}$ ). Data are expressed as mean $\pm \mathrm{SEM}$. Scale bar is $100 \mu \mathrm{M}$. Arrows indicate colocalization. 
A)

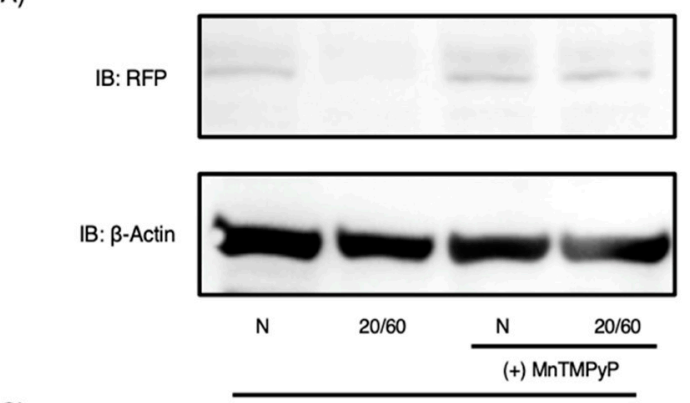

C)

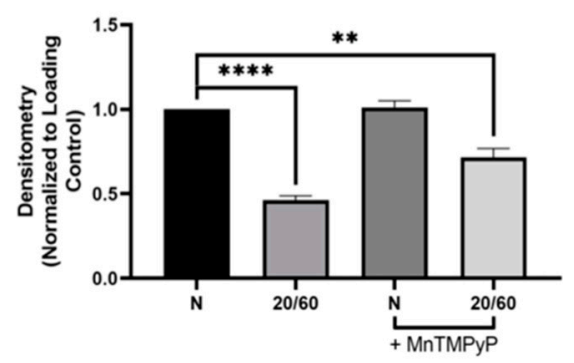

B)

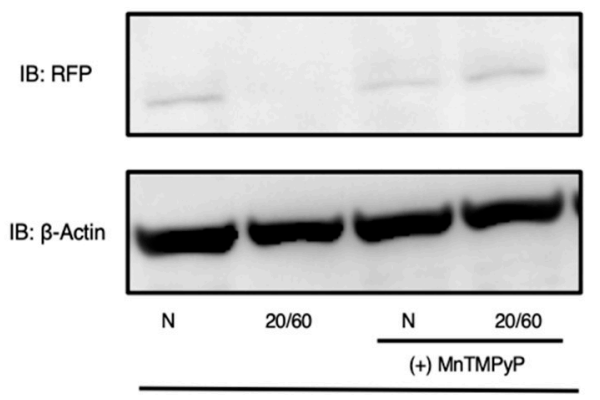

(+) GluA2-tdTomato

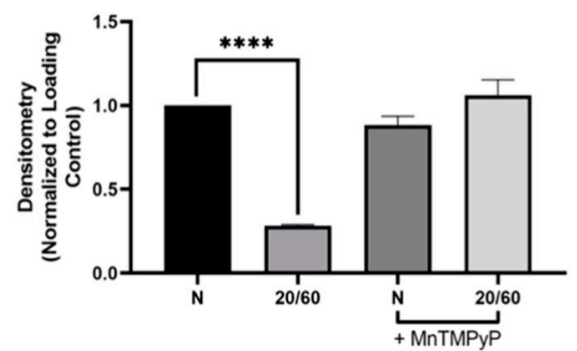

Figure 7. MnTMPyP prevented OGD/R-induced degradation of GluA1 and GluA2 AMPAR subunits. U-251 MG cells transfected with GluA1-tdTomato or GluA2-tdTomato and exposed to either normoxic or OGD/R conditions. (A) Representative Western blot demonstrating that pretreatment with MnTMPyP ameliorated OGD/R-induced decrease in total GluA1 protein levels. (C) Quantification (A) of total GluA1 protein levels normalized to $\beta$-Actin $(n=3)$. (B) Representative Western blot illustrating that pretreatment with MnTMPyP ameliorated OGD/R-induced decrease in total GluA2 protein levels. (D) Quantification (B) of total GluA2 protein levels normalized to $\beta$-Actin $(\mathrm{N}=3) .{ }^{* *} p<0.01$; ${ }^{* * *} p<0.0001$; ANOVA with Tukey's post hoc test comparing OGD/R conditions to corresponding control (normoxic \pm MnTMPyP). Data are expressed as mean \pm SEM.

\section{Discussion}

In this study, we have demonstrated that ischemic/reperfusion-induced internalization and subsequent endocytic trafficking of GluA1 and GluA2 AMPAR subunits to late endosomes is mediated in an oxidative stress signaling pathway. The loss of GluA2containing AMPARs at the plasma membrane following ischemia/reperfusion occurs in vulnerable areas of the brain, such as the hippocampus, leading to delayed neuronal death [9]. The subunit composition switch from GluA2-containing, $\mathrm{Ca}^{2+}$-impermeable AMPARs to GluA2-lacking, $\mathrm{Ca}^{2+}$-permeable AMPARs occurs via the internalization and degradation of the GluA2 subunit [41], transcriptional and translational downregulation of GluA2 levels [16], and the increase in GluA2-lacking AMPARs at the plasma membrane [14]. In this study, we have examined the endocytic trafficking pathways of both GluA1 and GluA2 AMPAR subunits following OGD/R and the role of oxidative stress in mediating these processes.

It is well-studied that oxidative stress exacerbates cell death following ischemia/ reperfusion [39,40,42-45]. There are three distinct temporal oxidative stress mechanisms that contribute to neuronal injury following ischemia/reperfusion. With hypoxic onset, mitochondria generate an initial burst of ROS followed closely by xanthine oxidase activation. Once reperfusion occurs, NADPH oxidase produces a large burst of ROS in a calciumdependent manner [22]. In this study, we observed a robust increase in ROS production during the reperfusion phase of OGD/R in U251-MG cells. Astrocytes do express NADPH oxidase [46], so it is possible that the large increase in ROS is due to activation of NADPH oxidase in U251-MG cells. Alternatively, there could be delayed ROS production from mitochondria and/or xanthine oxidase. Further studies using pharmacological inhibitors 
and/or genetic tools are needed to identify the source of ROS in our U251-MG OGD/R model system.

This study is the first to indicate that endocytic trafficking of GluA1 and GluA2 subunits can be modulated with ROS following OGD/R. Utilizing MnTMPyP, a superoxide dismutase mimetic, we identified ROS-mediated trafficking of GluA1 and GluA2 with $\mathrm{OGD} / \mathrm{R}$ that is distinct from agonist-induced internalization. MnTMPyP treatment had no effect on agonist-induced internalization of GluA1 and GluA2 subunits, but attenuated both the internalization and degradation of GluA1 and GluA2 subunits with OGD/R.

Under physiological conditions, endocytosis of GluA2 is mediated by protein kinase $C$ alpha (PKC $\alpha$ )-dependent phosphorylation of GluA2 Ser880 residue. PKC $\alpha$ is activated by increased intracellular calcium and is redox-sensitive [47-49]. Further studies are needed to examine the relationship between ROS and PKC $\alpha$ activation. Upon activation, $\mathrm{PKC} \alpha$ translocates the plasma membrane by protein interacting with C kinase 1 (PICK1) [50], where it phosphorylates GluA2 [51]. The phosphorylation of GluA2 at the Ser880 residue, and increased association with PICK1, increases the internalization of GluA2-containing AMPARs [19,52] thus reducing the surface population of AMPARs. This event allows for a transient increase in calcium permeable AMPARs at the plasma membrane, which is a critical component for LTP under physiologic conditions [53], but is harmful when uncontrolled during pathophysiological conditions like ischemia/reperfusion [13] (Figure 8).

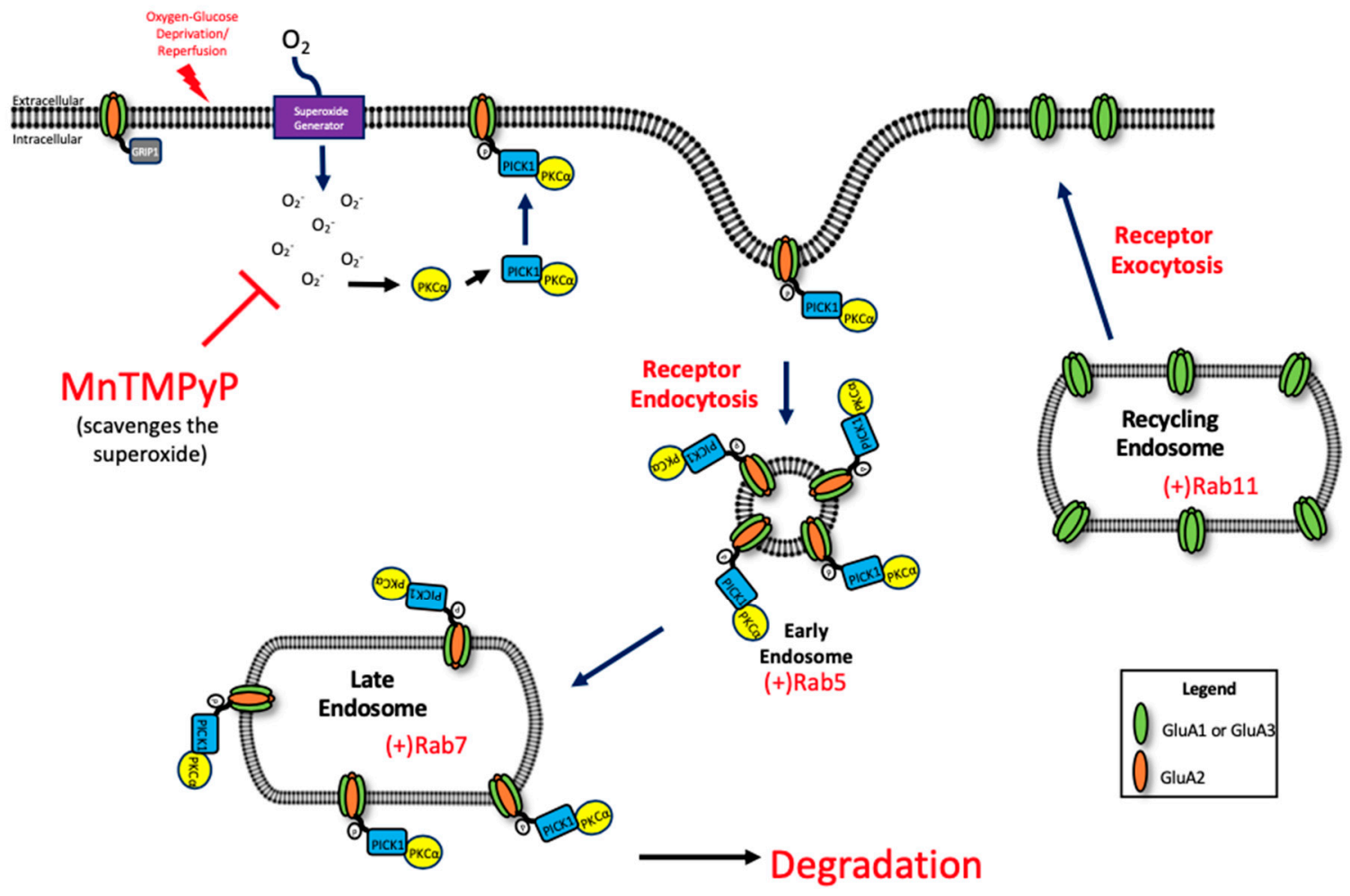

Figure 8. Potential mechanism of oxidative stress-mediated trafficking of GluA1 and GluA2 AMPAR subunits following OGD/R.

The present study examined the effect of superoxide on the internalization, degradation, and recycling of GluA1 and GluA2 AMPAR subunits with OGD/R in U251-MG cells. The superoxide scavenger, MnTMPyP, prevented both the internalization of both GluA1 and GluA2 receptor subunits following OGD/R. In the absence of superoxide, the degradation of GluA1 was partially rescued with OGD/R, whereas the degradation of GluA2 was completely prevented with MnTMPyP treatment. Interestingly, GluA1 was present within Rab11-positive recycling endosomes under both normoxic and OGD/R conditions, with MnTMPyP having no effect. This suggests that there is a pool of GluA1 
homomeric AMPARs that is unique to GluA1, as GluA2 was not present in Rab11-positive endosomes under any conditions studied.

The recycling of GluA1 homomeric AMPARs to the plasma membrane, a critical component of LTP [53], is a tightly regulated process. Activity-dependent endocytic sorting of GluA1 depends on phosphorylation [54] at the Ser845 residue by PKA, which promotes receptor insertion and decreases receptor endocytosis [55]. The fate of internalized GluA1containing AMPARs to either Rab7-containing endosomes, fated for degradation, or Rab11containing endosomes, fated for recycling, depends upon phosphorylation [56]. It has also been reported that ubiquitination of GluA1 facilitates agonist-induced endocytosis [57] and lysosomal targeting [58]. GluA1-containing, GluA2-lacking AMPARs are recruited to the plasma membrane surface during LTP by palmitoylation of A-kinase anchoring protein 150 (AKAP150), a scaffold that binds to and regulates GluA1 phosphorylation and trafficking [59]. Upon AMPA agonist stimulation, myosin $\mathrm{Vb}$ captures and mobilizes Rab11-positive, recycling endosomes for AMPAR insertion [60]. The mechanisms for GluA1 trafficking during LTP are well understood, but whether all these mechanisms are conserved during pathologic ischemic/reperfusion injury remains to be determined. It is particularly interesting that GluA1 homomeric AMPAR subunits are present within Rab11positive endosomes, but GluA2 homomeric AMPAR subunits are not during OGD/R. This suggests that there is an unknown differential trafficking mechanism between GluA1 and GluA2 with regards to receptor recycling during OGD/R.

We utilized an immortalized cell line in this study, which is a study limitation. It is unclear whether these results are reproducible in different cell lines, in primary cultures of neuronal cells, or in vivo, and further studies will need to be conducted to confirm these results.

This study is the first to examine how oxidative stress mediates endocytic trafficking of GluA1 and GluA2 AMPAR subunits following OGD/R, but further studies are needed to fully characterize the role of superoxide in mediating the endocytic trafficking and degradation of the GluA1 and GluA2 AMPAR subunits with OGD/R.

\section{Materials and Methods}

\subsection{Cell Culture}

U251-MG cells, an immortalized human astrocytoma cell line, were maintained in DMEM supplemented with $10 \%$ fetal bovine serum, $1 \times$ penicillin/streptomycin, $1 \times$ MEM nonessential amino acids, and $1 \times$ sodium pyruvate. All reagents for cell culture were purchased from Gibco (Gaithersburg, MD, USA). Once cells reached 75\% confluency, they were passaged.

\subsection{Transfection}

U251-MG cells were transiently transfected with GluA1-tdTomato, GluA1-eGFP, GluA2-tdTomato, or GluA2-eGFP, and either Rab5-cerulean, Rab7-RFP, or Rab11-RFP. Cells were transfected using Lipofectamine 2000 in Opti-mem media (Fisher Scientific, Pittsburgh, PA, USA) for $4 \mathrm{~h}$ before the transfection media was replaced with complete DMEM media. Experiments were performed $48 \mathrm{~h}$ following transfection.

\subsection{AMPA Stimulation}

Transfected U251-MG cells (75,000 cells/well on 6-well plate) were exposed to saturating conditions of AMPA $(100 \mu \mathrm{M})$ [61], cyclothiazide $(100 \mu \mathrm{M})$ [62] to prevent AMPAR desensitization, and MnTMPyP $(100 \mu \mathrm{M})[63,64]$ as previously indicated for 3 min before being removed and replaced with complete medium. U251-MG cells were fixed with $4 \%$ paraformaldehyde at time-points 5 and $10 \mathrm{~min}$. Cells were washed twice with phosphate buffered saline (PBS; Fisher Scientific, Pittsburgh, PA, USA) and mounted on slides for microscopy analysis. 


\subsection{Oxygen Glucose-Deprivation/Reperfusion (OGD/R)}

Transfected U251-MG cells were exposed to deoxygenated artificial cerebrospinal fluid (aCSF) without glucose (aCSF-glucose; $\mathrm{NaCl}$ [124 mM], $\mathrm{KCl}$ [2.5 mM], $\mathrm{NaHCO}_{3}$ [26 mM], $\mathrm{NaHPO}_{4}[1.25 \mathrm{mM}], \mathrm{CaCl}_{2}[2.5 \mathrm{mM}], \mathrm{MgCl}_{2}$ [1.5 mM], sucrose [10 mM] or Dglucose $[10 \mathrm{mM}]$ for reperfusion conditions (aCSF+glucose)) in a hypoxic chamber for $20 \mathrm{~min}$. aCSF-glucose was deoxygenated with nitrogen for $18 \mathrm{~h}$ prior to the experiment to ensure hypoxic conditions. aCSF-glucose was replaced with aCSF+glucose and cells were reperfused at various time-points: $0,5,15,30$, or $60 \mathrm{~min}$. Experiments were conducted in the presence of absence of MnTMPyP [100 $\mu \mathrm{M}$ ], a superoxide dismutase mimetic. U251MG cells were either prepared for Western blotting analysis or fluorescent microscopy. Normoxic controls were time-matched to the longest OGD/R time-point.

\subsection{Microscopy}

Following OGD/R or AMPA stimulation experiments, transfected U251-MG cells were imaged via confocal microscopy (60X objective), Olympus FluoView1000/IX81 confocal microscope system (Olympus Corporations of the Americas Headquarters, Center Valley, PA, USA) and colocalization coefficients (Pearson's Correlation Coefficient) were obtained using FIJI software (freely available from National Institutes of Health, Bethesda, MD, USA). All microscopy and data analyses were conducted in a blind manner.

\subsection{Western Blotting}

Protein concentration was determined using a bicinchoninic acid assay (BCA; Thermo Fisher Scientific, Waltham, MA, USA) and samples were heated at $100{ }^{\circ} \mathrm{C}$ in LDS/reducing agent buffer (Thermo Fisher Scientific, Waltham, MA, USA) and resolved via sodium dodecyl sulfate-polyacrylamide gel electrophoresis (SDS-PAGE). Samples were then transferred to a nitrocellulose membrane (Bio-Rad, Berkeley, CA, USA). Blots were blocked for one hour at room temperature with $5 \%(w / v)$ non-fat dry milk in tris buffered saline, $0.1 \%(v / v)$ tween-20, pH 7.5 (TBS-T). After blocking, blots were incubated with the primary antibody overnight at $4{ }^{\circ} \mathrm{C}$ at the concentration indicated. Blots were incubated with the secondary antibody for $1 \mathrm{~h}$ at room temperature. The following antibodies were used: anti-RFP (1:500; Invitrogen, Waltham, MA, USA), anti- $\beta$-Actin (1:10,000; Cell Signaling, Danvers, MA, USA), anti-mouse (1:2000; Cell Signaling, Danvers, MA, USA), and anti-rabbit (1:2000; Cell Signaling, Danvers, MA, USA). Immunoreactive bands were visualized and captured with a Fuji imaging system using enhanced chemiluminescence. Bands were analyzed using Fuji Image-Gauge software (Fujifilm North America Corporation, Valhalla, NY, USA).

\subsection{Trypan Blue Exclusion}

Following OGD/R, U251-MG cells were incubated in trypsin/EDTA $(0.05 \%)$ and centrifuged at $1000 \times g$ for $10 \mathrm{~min}$. The cell pellet was resuspended in complete medium and trypan blue (1:1 dilution). Cell viability was determined using trypan blue exclusion on Countess II Cell Counter (Thermo Fisher Scientific, Waltham, MA, USA).

\subsection{NBT Assay}

U251-MG cells were plated at $5 \times 10^{4}$ in 6 well plates and, once they reached $70 \%$ confluency, were used for experiments. NBT assay was adapted from $[65,66]$. Briefly, after $4 \mathrm{~h}$ of serum starvation, $0.5 \mathrm{mg} / \mathrm{mL}$ NBT was added to cells and incubated for one hour. Excess NBT was washed away 3 times with warmed PBS. U251-MG cells underwent $20 \mathrm{~min}$ of OGD and various reperfusion time points: $0,15,30$, or 60 min with or without MnTMPyP treatment. Phorbol 12-myristate 13-acetate (PMA; $1 \mu \mathrm{M}$; Sigma Aldrich, St. Louis, MO, USA) was used as a positive control. Following treatment, cells were fixed with absolute methanol, air dried, and formazan deposits were dissolved in 100\% dimethyl sulfoxide and $\mathrm{KOH}[2 \mathrm{M}]$. Absorbance was measured at $620 \mathrm{~nm}$ with Spectra Max Gemini M2 plate reader (Molecular Devices, Sunnyvale, CA, USA). 


\subsection{Data Analysis and Scientific Rigor}

Either Student's $t$-test or one-way ANOVA with Tukey's post hoc test were conducted using GraphPad Prism 8 software to determine statistical significance. All imaging and analyses were performed blindly.

Author Contributions: Conceptualization, L.M.A. and D.A.J., methodology, L.M.A., C.J.D., M.S., I.S. and D.A.J.; software, L.M.A.; validation, L.M.A., C.J.D., M.S. and I.S.; formal analysis, L.M.A., C.J.D., M.S. and I.S.; investigation, L.M.A., C.J.D., M.S. and I.S.; writing-original draft preparation, L.M.A. and D.A.J.; writing-review and editing, L.M.A., C.J.D., M.S., I.S. and D.A.J.; supervision, D.A.J.; project administration, D.A.J.; funding acquisition, D.A.J. All authors have read and agreed to the published version of the manuscript.

Funding: This research received start-up funding from Washington State University, Department of Pharmaceutical Sciences and Molecular Medicine. This research received funding from the Center for Structural and Functional Neuroscience, University of Montana (P20RR015583).

Institutional Review Board Statement: Not Applicable.

Informed Consent Statement: Not Applicable.

Data Availability Statement: All data are present within the manuscript or available by request to corresponding author, Darrell A. Jackson (darrell.jackson@wsu.edu).

Acknowledgments: U251-MG cells were generously gifted by Richard Bridges, University of Montana. GluA1 and GluA2 fluorescently tagged plasmids were generously gifted from Richard Huganir, Johns Hopkins. We acknowledge the WSU Microscopy Core for use of their facilities and equipment. We acknowledge the University of Montana Molecular Histology \& Fluorescence Imaging Core Facility for use of their equipment.

Conflicts of Interest: The authors declare no conflict of interest.

$\begin{array}{ll}\text { Abbreviations } & \\ \text { aCSF } & \text { Artificial cerebrospinal fluid } \\ \text { aCSF+glucose } & \text { aCSF supplemented with glucose } \\ \text { aCSF-glucose } & \text { aCSF supplemented with sucrose } \\ \text { AMPAR } & \text { (-amino-3-hydroxy-5-methyl-4-isoxazolepropionic acid receptor } \\ \text { BCA } & \text { Bicinchoninic Acid Assay } \\ \text { DOAJ } & \text { Directory of Open Access Journals } \\ \text { DND } & \text { Delayed Neuronal Death } \\ \text { LTD } & \text { Long-Term Depression } \\ \text { LTP } & \text { Long-Term Potentiation } \\ \text { MDPI } & \text { Multidisciplinary Digital Publishing Institute } \\ \text { MnTMPyP } & \text { Mn(III)tetrakis(1-methyl-4-pyridyl)porphyrin } \\ \text { NBT } & \text { Nitroblue Tetrazolium } \\ \text { NMDAR } & \text { N-methyl-D-aspartate receptor } \\ \text { OGD/R } & \text { Oxygen Glucose-deprivation/Reperfusion } \\ \text { PBS } & \text { Phosphate Buffered Saline } \\ \text { PICK1 } & \text { Protein Interacting with C Kinase 1 } \\ \text { PKC } \alpha & \text { Protein Kinase C alpha } \\ \text { PMA } & \text { Phorbol 12-myristate 13-acetate } \\ \text { ROS } & \text { Reactive Oxygen Species } \\ \text { SDS-PAGE } & \text { Sodium Dodecylsulfate-Polyacrylamide Gel Electrophoresis } \\ \text { TBS-T } & \text { Tris Buffered Saline + Tween } \\ & \end{array}$

\section{References}

1. Yang, Q.; Tong, X.; Shieb, L.; Vaughan, A.; Gillespie, C.; Wiltz, J.L.; King, S.C.; Odom, E.; Merritt, R.; Hong, Y. Vital signs: Recent trends in stroke death rates-United States, 2000-2015. MMWR Morb. Mortal. Wkly. Rep. 2017, 66, 933-939. [CrossRef]

2. Ford, L.M.; Sanberg, P.R.; Norman, A.B.; Fogelson, M.H. MK-801 prevents hippocampal neurodegeneration in neonatal hypoxicischemic rats. Arch. Neurol. 1989, 46, 1090-1096. [CrossRef] 
3. Mitani, A.; Namba, S.; Ikemune, K.; Yanase, H.; Arai, T.; Kataoka, K. Postischemic enhancements of N-Methyl-D-Aspartic Acid (NMDA) and non-NMDA receptor-mediated responses in hippocampal CA1 pyramidal neurons. J. Cereb. Blood Flow Metab. 1998, 18, 1088-1098. [CrossRef]

4. Camacho, A.; Massieu, L. Role of glutamate transporters in the clearance and release of glutamate during ischemia and its relation to neuronal death. Arch. Med. Res. 2005, 37, 11-18. [CrossRef]

5. Faden, A.; Demediuk, P.; Panter, S.S.; Vink, R. The role of excitatory amino acids in traumatic brain injury. Science 1989, 244, 798-800. [CrossRef]

6. Mcintosh, T.K.; Vink, R.; Soares, H.; Hayes, R.; Simon, R. Effects of the N-methyl-D-aspartate receptor blocker MK-801 on neurologic function after experimental brain injury. J. Neurotrauma 1989, 6, 247-259. [CrossRef]

7. Takagi, N.; Shinno, K.; Teyes, L.; Bissoon, N.; Wallace, M.C.; Gurd, J.W. Transient ischemia differentially increases tyrosine phosphorylation of NMDA receptor subunits 2A and 2B. J. Neurochem. 1997, 69, 1060-1065. [CrossRef]

8. Liu, Y.; Wong, T.P.; Aarts, M.; Roovakkers, A.; Liu, L.; Lai, T.W.; Wu, D.C.; Lu, J.; Tymianski, M.; Craig, A.M.; et al. NMDA receptor subunits have differential roles in mediating excitotoxic neuronal death both in vitro and in vivo. J. Neurosci. 2007, 27, 2846-2857. [CrossRef]

9. Liu, S.; Lau, L.; Wei, J.; Zhu, D.; Shengwei, Z.; Sun, H.; Fu, Y.; Liu, F.; Lu, Y. Expression of Ca ${ }^{2+}$-permeable AMPA receptor channels primes cell death in transient forebrain ischemia. Cell Press 2004, 43, 43-55. [CrossRef]

10. Yin, H.; Sensi, S.; Ogoshi, F.; Weiss, J.H. Blockade of $\mathrm{Ca}^{2+}$-permeable AMPA/Kainate channels decreases oxygen-glucose deprivation-induced $\mathrm{Zn}^{2+}$ accumulation and neuronal loss in hippocampal pyramidal neurons. J. Neurosci. 2002, 22, 1273-1279. [CrossRef]

11. Anzai, T.; Tsuzuki, K.; Yamada, N.; Hayashi, T.; Iwakuma, M.; Inada, K.; Kamevama, K.; Saji, M. Overexpression of Ca ${ }^{2+}$ permeable AMPA receptor promotes delayed cell death of hippocampal CA1 neurons following transient forebrain ischemia. Neurosci. Res. 2003, 46, 41-51. [CrossRef]

12. Calderone, A.; Jover, T.; Mashiko, T.; Noh, K.M.; Tanaka, H.; Bennett, M.V.; Zukin, R.S. Late calcium EDTA rescues hippocampal CA1 neurons from global ischemia-induced death. J. Neurosci. 2004, 24, 9903-9913. [CrossRef]

13. Noh, K.M.; Yokota, H.; Mashiko, T.; Castillo, P.E.; Zukin, R.S.; Bennett, M.V. Blockade of calcium-permeable AMPA receptors protects hippocampal neurons against global ischemia-induced death. Proc. Natl. Acad. Sci. USA 2005, 102, 12230-12235. [CrossRef]

14. Liu, B.; Mao, M.; Mielke, J.G.; Ning, K.; Chen, Y.; Li, L.; El-Hayek, Y.H.; Gomez, E.; Zukin, R.S.; Fehlings, M.G.; et al. Ischemia insults direct glutamate receptor subunit 2-lacking AMPA receptors to synaptic sites. J. Neurosci. 2006, 26, 5309-5319. [CrossRef]

15. Blanco-Suarez, E.; Hanley, J.G. Distinct subunit-specific a-amino-3-hydroxy-5-methyl-4-isoxazolepropionic acid (AMPA) receptor trafficking mechanisms in cultured cortical and hippocampal neurons in response to oxygen and glucose deprivation. J. Biol. Chem. 2014, 298, 4644-4651. [CrossRef]

16. Pellegrini-Giampietry, D.E.; Gorter, J.A.; Bennett, M.V.L.; Zukin, R.S. The GluR2 (GluR-B) hypothesis: Ca(2+)-permeable AMPA receptors in neurological disorders. Trends Neurosci. 1997, 20, 464-470. [CrossRef]

17. Arundine, M.; Tymianski, M. Molecular mechanisms of calcium-dependent neurodegeneration in excitotoxicity. Cell Calcium 2003, 34, 325-337. [CrossRef]

18. Shepherd, J.D.; Huganir, R.L. The cell biology of synaptic plasticity. Annu. Rev. Cell Biol. 2007, 23, 613-643. [CrossRef]

19. Terashima, A.; Pelkey, K.A.; Rah, J.C.; Such, Y.H.; Roche, K.W.; Collingridge, G.L. An essential role for PICK1 in NMDA receptor-dependent bidirectional synaptic plasticity. Neuron 2008, 57, 872-882. [CrossRef]

20. Kuner, T.; Beck, C.; Sakmann, B.; Seeburg, P.H. Channel-lining residues of the AMPA receptor M2 segment: Structural environment of the Q/R site and identification of the selectivity filter. J. Neurosci. 2001, 21, 4162-4172. [CrossRef]

21. Kwak, S.; Weiss, J.H. Calcium-permeable AMPA channels in neurodegenerative disease and ischemia. Curr. Opin. Neurobiol. 2006, 16, 281-287. [CrossRef]

22. Abramov, A.Y.; Scorziello, A.; Duchen, M.R. Three distinct mechanisms generate oxygen free radicals in neurons and contribute to cell death during anoxia and reoxygenation. J. Neurosci. 2007, 27, 1129-1138. [CrossRef]

23. Allen, C.L.; Bayraktutan, U. Oxidative stress and its role in the pathogenesis of ischaemic stroke. Int. J. Stroke 2009, 4, 461-470. [CrossRef]

24. Raghu, H.; Doni, C.S.; Dinh, D.H.; Gujrati, M.; Rao, J.S. Specific knockdown of uPA/uPAR attenuates invasion in glioblastoma cells and xenografts by inhibition of cleavage and trafficking of Notch-1 receptor. Mol. Cancer 2011, 10. [CrossRef]

25. Cassoni, P.; Senetta, R.; Castellano, I.; Ortolan, E.; Bosco, M.; Magnani, I.; Ducati, A. Caveolin-1 expression is variably displayed in astroglial-derived tumors and absent in oligodendrogliomas: Concrete premises for a new reliable diagnostic marker in gliomas. Am. J. Surg. Pathol. 2007, 31, 760-769. [CrossRef]

26. Zhang, C.; Zhang, X.; Xu, R.; Huang, B.; Chen, A.-J.; Li, C.; Wang, J.; Li, X.-G. TGF $\beta_{2}$ initiates autophagy via Smad and non-Smad pathway to promote glioma cells' invasion. J. Exp. Clin. Cancer Res. 2017, 16. [CrossRef]

27. Xu, R.; Ji, J.; Zhang, X.; Han, M.; Zhang, C.; Xu, Y.; Wei, Y.; Wang, S.; Huang, B.; Chen, A.; et al. PDGFA-PDGFR $\alpha$-regulated GOLM1 promotes human glioma progression through activation of AKT. J. Exp. Clin. Cancer Res. 2017, 36. [CrossRef]

28. Lee, Y.-S.; Bae, Y.; Park, N.; Yoo, J.C.; Cho, C.-H.; Ryoo, K.; Hwang, E.M.; Park, J.-Y. Surface expression of the Anoctamin-1 (ANO1) channel is suppressed by protein-protein interactions with $\beta$-COP. Biochem. Biophys. Res. Commun. 2016, 475, 216-222. [CrossRef] 
29. Johnson, E.E.; Overmeyer, J.H.; Gunning, W.T.; Maltese, W.A. Gene silencing reveals a specific function of hVps34 phosphatidylinositol 3-kinase in late versus early endosomes. J. Cell Sci. 2006, 119, 1219-1232. [CrossRef]

30. Overmeyer, J.H.; Young, A.M.; Bhanot, H.; Maltese, W.A. A chalcone-related small molecule that induces methuosis, a novel form of non-apoptotic cell death, in glioblastoma cells. Mol. Cancer 2011, 10. [CrossRef]

31. Stenmark, H.; Olkkonen, V.M. The Rab GTPase family. Genome Biol. 2001, 2. [CrossRef]

32. Tin, D.-T.; Huganir, R.L. PICK1 and phosphorylation of the glutamate receptor 2 (GluR2) AMPA receptor subunit regulates GluR2 recycling after the NMDA receptor-induced internalization. J. Neurosci. 2007, 27, 13903-13908.

33. Thorsen, T.S.; Madsen, K.L.; Rebola, N.; Rathie, M.; Anggono, V.; Bach, A.; Moreira, I.S.; Stuhr-Hansen, N.; Dyhring, T.; Peters, D.; et al. Identification of a small-molecule inhibitor of the PICK1 PDZ domain that inhibits hippocampal LTP and LTD. Proc. Natl. Acad. Sci. USA 2010, 107, 413-418. [CrossRef] [PubMed]

34. Rathie, M.; Fang, H.; Bachman, J.L.; Anggono, V.; Gether, U.; Huganir, R.L.; Madsen, K.L. AMPA receptor pH-luorin- GluA1 reports NMDA receptor-induced intracellular acidification in hippocampal neurons. Proc. Natl. Acad. Sci. USA 2013, 110, 14426-14431. [CrossRef] [PubMed]

35. Gorvel, J.P.; Chavrier, P.; Zerial, M.; Gruenberg, J. rab5 controls early endosome fusion in vitro. Cell 1991, 64, 915-925. [CrossRef]

36. Mukhopadhyay, A.; Funato, K.; Stahl, P.D. Rab7 regulates transport from early to late endocytic compartments in Xenopus oocytes. J. Biol. Chem. 1997, 272, 13055-13059. [CrossRef]

37. Lock, J.G.; Stow, J.L. Rab11 in recycling endosomes regulates the sorting and basolateral transport of e-cadherin. Mol. Biol. Cell 2005, 16, 1744-1755. [CrossRef]

38. Kuwabara, W.M.T.; Xhang, L.; Schuiki, I.; Curi, R.; Volchuk, A.; Alba-Luoreiro, T.C. NADPH oxidase-dependent production of reactive oxygen species induces endoplasmic reticulum stress in neutrophil-like HL60 cells. PLoS ONE 2015, 10. [CrossRef]

39. Beske, P.H.; Byrnes, N.M.; Astruc-Diaz, F.; Jackson, D.A. Identification of NADPH oxidase as a key mediator in the postischemia-induced sequestration and degradation of the GluA2 AMPA receptor subunit. J. Neurochem. 2015, 132, 504-519. [CrossRef]

40. Jackson, D.A.; Beske, P.H.; Byrnes, N.M.; Astruc-Diaz, F. The post-ischemic increase in GluA2 ser880 phosphorylation involves NADPH oxidase. J. Pharm. Sci. Therap. 2018, 4, 170-181. [CrossRef]

41. Dixon, R.M.; Mellor, J.R.; Hanley, J.G. PICK1-mediated glutamate receptor subunit 2 (GluR2) trafficking contributes to cell death in oxygen/glucose-deprived hippocampal neurons. J. Biol. Chem. 2009, 282, 14230-14235. [CrossRef] [PubMed]

42. Vornov, J.J.; Park, J.; Thomas, A.G. Regional vulnerability to endogenous oxidative stress in organotypic hippocampus culture. Exp. Biol. 1997, 149, 109-122.

43. Wang, R.M.; Zhang, Q.G.; Zhang, G.Y. Activation of ERK5 is mediated by N-methyl-D-aspartate receptor and L-type voltage-gated calcium channel via Src involving oxidative stress after cerebral ischemia in rat hippocampus. Neurosci. Lett. 2004, 357, 13-16. [CrossRef] [PubMed]

44. Zhang, Q.; Zhang, G.; Meng, F.; Tian, H. Biphasic activation of apoptosis signal-regulating kinase 1-stress-activated protein kinase 1-c-Jun N-terminal protein kinase pathway is selectively mediated by $\mathrm{Ca}^{2+}$-permeable alpha-amino-3-hydroxy-5-methyl-4isoxazolepropionate receptors involving oxidative stress following brain ischemia in rat hippocampus. Neurosci. Lett. 2003, 337, 51-55. [PubMed]

45. Beske, P.H.; Jackson, D.A. NADPH oxidase mediates the oxygen-glucose deprivation/reperfusion-induced increase in the tyrosine phosphorylation of the $\mathrm{N}$-methyl-D-aspartate receptor NR2A subunit in retinoic acid differentiated SH-SY5Y cells. J. Mol. Signal. 2012, 7, 15. [CrossRef] [PubMed]

46. Abramov, A.Y.; Jacobson, J.; Wientjes, F.; Hothersall, J.; Canevari, L.; Duchen, M.R. Expression and modulation of an NADPH oxidase in mammalian astrocytes. J. Neurosci. 2005, 25, 9176-9184. [CrossRef]

47. Rimessi, A.; Rizzuto, R.; Pinton, P. Differential recruitment of PKC isoforms in HeLa cells during redox stress. Cell Stress Chaperones 2007, 12, 291-298. [CrossRef]

48. Ward, N.E.; Pierce, D.S.; Chung, S.E.; Gravitt, K.R.; O’Brian, C.A. Irreversible inactivation of protein kinase C by glutathione. J. Biol. Chem. 1998, 273, 12558-12566. [CrossRef]

49. Tuttle, K.R.; Anderberg, R.J.; Cooney, S.K.; Meek, R.L. Oxidative stress mediates protein kinase C activation and advanced glycation end production formation in a mesangial cell model of diabetes and high protein diet. Am. J. Nephrol. 2009, 29, 171-180. [CrossRef]

50. Perez, J.L.; Khatri, L.; Chang, C.; Srivastava, S.; Osten, P.; Ziff, E.B. PICK1 targets activated protein kinase c alpha to AMPA receptor clusters in spines of hippocampal neurons and reduced surface levels of the AMPA-type glutamate receptor subunit 2. J. Neurosci. 2001, 21, 5417-5428. [CrossRef]

51. Lu, W.; Ziff, E.B. PICK1 interacts with ABP/GRIP to regulate AMPA receptor trafficking. Neuron 2005, 47, 407-421. [CrossRef] [PubMed]

52. Terashima, A.; Cotton, L.; Dev, K.K.; Meyer, G.; Zaman, S.; Duprat, F. Regulation of synaptic strength and AMPA receptor subunit composition by PICK1. J. Neurosci. 2004, 24, 5381-5390. [CrossRef] [PubMed]

53. Seidenman, K.J.; Steinberg, J.P.; Huganir, R.; Malinow, R. Glutamate receptor subunit 2 serine 880 phosphorylation modulates synaptic transmission and mediates plasticity in CA1 pyramidal cells. J. Neurosci. 2003, 23, 9220-9228. [CrossRef] [PubMed]

54. Ehlers, M.D. Reinsertion or degradation of AMPA receptors determined by activity-dependent endocytic sorting. Neuron 2000, 28, 511-525. [CrossRef] 
55. Man, H.-Y.; Sekine-Aizawa, Y.; Huganir, R.L. Regulation of $\alpha$-amino-3-hydroxy-5-methyl-4-isoxazolepropionic acid receptor trafficking through PKA phosphorylation of the Glu receptor 1 subunit. Proc. Natl. Acad. Sci. USA 2007, 104, 3579-3584. [CrossRef]

56. Fernandez-Monreal, M.; Brown, T.C.; Royo, M.; Esteban, J.A. The balance between receptor recycling and trafficking toward lysosomes determines synaptic strength during long-term depression. J. Neurosci. 2012, 32, 13200-13205. [CrossRef]

57. Lin, A.; Hou, Q.; Jarzylo, L.; Amato, S.; Gilbert, J.; Shang, F.; Man, H.-Y. Nedd4-medated AMPA receptor ubiquitination regulates receptor turnover and trafficking. J. Neurochem. 2011, 119, 27-39. [CrossRef]

58. Schwartz, L.A.; Hall, B.J.; Patrick, G.N. Activity-dependent ubiquitination of GluA1 mediates a distinct AMPA receptor endocytosis and sorting pathway. J. Neurosci. 2010, 30, 16718-16729. [CrossRef]

59. Purkey, A.M.; Woolfrey, K.M.; Crosby, K.C.; Stich, D.G.; Chick, W.S.; Aoto, J.; Dell'Acqua, M.L. AKAP150 palmitoylation regulates synaptic incorporation of $\mathrm{Ca}^{2+}$-permeable AMPA receptors to control LTP. Cell Rep. 2018, 25, 974-987. [CrossRef]

60. Wang, Z.; Edwards, J.G.; Riley, N.; Proyance, D.W.; Karcher, R.; Li, X.-D.; Davison, I.G.; Ikebe, M.; Mercer, J.A.; Kauer, J.A.; et al Myosin $\mathrm{Vb}$ mobilizes recycling endosomes and AMPA receptors for postsynaptic plasticity. Cell 2008, 135, 535-548. [CrossRef]

61. Chen, C.-Y.; Matt, L.; Hell, J.W.; Rogawski, M.A. Perampanel inhibition of AMPA receptor currents in cultured hippocampal neurons. PLoS ONE 2014, 9. [CrossRef]

62. Fedorova, I.M.; Magazanik, L.G.; Tikhonov, D.B. Characterization of ionotropic glutamate receptors in insect neuro-muscular junction. Comp. Biochem. Physiol. Toxicol. Pharmacol. 2009, 149, 275-280. [CrossRef] [PubMed]

63. MacKenzie, A.; Martin, W. Loss of endothelium-derived nitric oxide in rabbit aorta by oxidant stress: Restoration by superoxide dismutase mimetics. Br. J. Pharmacol. 1998, 124, 719-728. [CrossRef] [PubMed]

64. Nilkantan, V.; Maenpaa, C.; Jia, G.; Roman, R.J.; Park, F. 20-HETE-mediated cytotoxicity and apoptosis in ischemic kidney epithelial cells. Am. J. Physiol. Renal Physiol. 2008, 294, 562-570. [CrossRef] [PubMed]

65. Aukrust, P.; Muller, F.; Froland, S.S. Enhanced generation of reactive oxygen species in monocytes from patients with common variable immunodeficiency. Clin. Exp. Immunol. 1994, 97, 232-238. [CrossRef]

66. Choi, H.S.; Kim, J.W.; Cha, Y.N.; Kim, C.A. A quantitative nitroblue tetrazolium assay for determining intracellular superoxide anion production in phagocytic cells. J. Immunoass. Immunochem. 2006, 27, 31-44. [CrossRef] 